\title{
Locally Advanced Bone Sarcoma
}

National Cancer Institute

\section{Source}

National Cancer Institute. Locally Advanced Bone Sarcoma. NCI Thesaurus. Code C153070.

Bone sarcoma that has spread from its original site of growth to nearby tissues or lymph nodes. 